in vivo $34: 2249-2258(2020)$

doi:10.21873/invivo.12035

Review

\title{
Maxillary Ameloblastoma: A Review With Clinical, Histological and Prognostic Data of a Rare Tumor
}

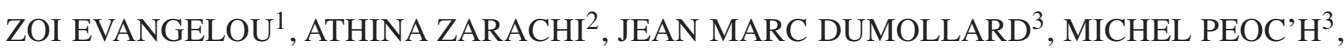 \\ IOANNIS KOMNOS ${ }^{2}$, IOANNIS KASTANIOUDAKIS ${ }^{2}$ and GEORGIA KARPATHIOU ${ }^{1,3}$ \\ Departments of ${ }^{1}$ Pathology and Otorhinolaryngology, and \\ ${ }^{2}$ Head and Neck Surgery, University Hospital of Ioannina, Ioannina, Greece; \\ ${ }^{3}$ Department of Pathology, University Hospital of Saint-Etienne, Saint-Etienne, France
}

\begin{abstract}
Diagnosis of odontogenic tumors can be challenging due to their rarity and diverse morphology, but when arising near the tooth, the diagnosis could be suspected. When their location is not typical, like inside the paranasal sinuses, the diagnosis is less easy. Maxillary ameloblastomas are exceedingly rare with only sparse information on their epidemiological, histological and genetic characteristics. The aim of this report is to thoroughly review the available literature in order to present the characteristics of this tumor. According to available data, maxillary ameloblastomas can occur in all ages but later than mandible ones, and everywhere within the maxillary region without necessarily having direct contact with the teeth. No sex preference has been shown. The most common histological patterns seen in this location are the follicular and plexiform ones. Maxillary ameloblastomas are locally aggressive neoplasms, thus therapy aims for excision including normal bone beyond the lesion. In contrast to mandible ameloblastomas, maxillary ones most commonly show mutations of the SMO gene. Furthermore, differential tumor diagnosis is thoroughly discussed in the present review.
\end{abstract}

Odontogenic tumors are rare and can pose diagnostic difficulties for non-specialized pathologists. Nevertheless, when the location is typical, i.e. molar region and when the histology shows the characteristic features of odontogenic

This article is freely accessible online.

Correspondence to: Georgia Karpathiou, MD, BSc, Ph.D., Department of Pathology, University Hospital of Saint-Etienne, 42055 CEDEX 2, St-Etienne, France. E-mail: gakarpath@yahoo.gr

Key Words: Odontogenic tumor, sinonasal tumor, nasal polyp, head and neck, rare tumor, adamantinoma, review. neoplasms, diagnosis could be straightforward. In locations outside the oral cavity or when rare histological variants are found, suspecting the correct diagnosis can be challenging. This is especially true for maxillary ameloblastomas, which are rare, possibly leading to low awareness of this neoplasm at this location and often show non-classical morphology, thus, rendering its diagnosis more complicated.

Thus, the aim of this review is to define and thoroughly describe maxillary ameloblastomas based on the available literature after a short introduction in the entity of ameloblastoma.

Introduction to Ameloblastomas. Ameloblatoma, initially called adamantinoma (from the greek word adamantinos $\alpha \delta \alpha \mu \alpha ́ v \tau ı v o \varsigma<\dot{\alpha}-\delta \alpha ́ \mu \alpha \varsigma$, meaning very hard) from Broca (1) in 1867 , belongs to odontogenic tumors. Odontogenic tumors are rare entities that constitute a heterogenous group of neoplasms with a variety of histological types and clinical behaviors (2). Their classification has seen many changes, from attempts to classify these lesions based on their histogenesis (3) or mechanisms of differentiation (4) to reach the final classification scheme set by the World Health Organization in 2017 (5) (Table I). Among all odontogenic tumors, ameloblastomas are the most common to encounter. Based on WHO 2017 (5), ameloblastomas are divided into i. ameloblastoma, which includes the previously named conventional, solid/multicystic and intraosseous ameloblastoma, ii. ameloblastoma, unicystic type, iii. ameloblastoma, extraosseous/peripheral type which includes the previously named soft tissue ameloblastoma, ameloblastoma of mucosal origin or of the gingiva and iv. metastasizing ameloblastoma.

Ameloblastomas are unusual entities that consist of approximately $1 \%$ of all benign tumors and cysts of the jaw (6). Their incidence is estimated to be 0.5 cases per million person-years worldwide (7), although in South Africa a slightly higher incidence has been reported (8). There is no 
Table I. WHO 2017 classification of odontogenic tumors (5).

Malignant odontogenic tumors

Ameloblastic carcinoma

Primary intraosseous

carcinoma, NOS

Sclerosing odontogenic carcinoma

Clear cell odontogenic carcinoma

Ghost cell odontogenic carcinoma

Odontogenic carcinosarcoma

Odontogenic sarcoma
Histological features similar to ameloblastoma but with significant atypia and mitotic activity

Diagnosis of exclusion. Almost all lesions are composed of malignant nests or islands of squamous epithelium with minimal keratinization

Sclerotic stroma in which bland, most commonly, compressed cells are found or less commonly arranged in thin cords or nests. Mitoses are infrequent.

Neoplasm composed of sheets and islands of vacuolated and glycogen rich clear cells. At the periphery of the islands there is a basaloid cell population (biphasic pattern).

Highly infiltrating cystic or solid lesion composed of malignant rounded epithelial cells with high mitotic activity, variable number of ghost cells and aberrant keratinization. Dentine and necrosis may be present.

A neoplasm similar to ameloblastic fibrosarcoma but with both mesenchymal and epithelial components being malignant

Bland epithelial component in variable amounts admixed with malignant stromal component showing nuclear crowding, atypia and increased mitoses.

Benign epithelial odontogenic tumors

Ameloblastoma

Ameloblastoma, unicystic type

Ameloblastoma, extraosseous/ peripheral type

Metastasizing ameloblastoma

Squamous odontogenic tumor

Calcifying epithelial odontogenic tumor

Adenomatoid odontogenic tumour
Odontogenic epithelial islands peripherally palisaded by columnar cells with reversed polarity filled with loosely arranged angulated cells (simulating the stellate reticulum).

Intraosseous cyst focally lined by characteristically ameloblastous epithelium (luminal type) or with additional intraluminal epithelial proliferations (intraluminal type).

Ameloblastoma confined to the soft tissues, with no osseous involvement.

Simultaneous existence of ameloblastoma in a distal organ (e.g. lungs, lymph nodes, bones etc.) and primary ameloblastoma of wither the mandible or the maxilla both with benign histological features

Islands composed of bland epithelial cells showing squamous differentiation towards the center. The peripheral cells are flattened.

Polyhedral neoplastic cells with abundant cytoplasm, pleomorphic nuclei and low mitotic rate organized in island, cords, trabecula or sheets. Characteristic extracellular eosinophilic secretion (odontogenic amyloid protein) that ultimately calcifies into concentric rings (Liesegang rings)

Oftenncapsulated tumor with variable sized duct-like spaces lined by columnar or cuboidal epithelium with the nuclei displaced away from the lumen. Minimal stroma with spindled cells. Frequent eosinophilic material.

Benign mixed epithelial and mesenchymal odontogenic tumors

Ameloblastic fibroma

Mesenchymal component: myxoid stroma with abundant spindle cells. Epithelial component: elongated strands with two tight epithelial layers of cuboidal or columnar epithelium. Occasionally there is a thickening towards the edges of the strands forming a stellate-reticulum like area.

Primordial odontogenic tumour

Loose fibrous tissue and stellate fibroblasts with minimal collagen deposition. The tumor is covered by columnar or cuboidal epithelium with underlying increased stroma cellularity

Odontoma

Compound: multiple teeth exhibiting dentin, cementum, enamel matrix, and pulp. Complex: disorganized or haphazard arrangement of pulpal tissues, enamel or dentin.

Dentinogenic ghost cell tumour Ameloblastomatous cells with or without microcystic formation, basaloid type cells arranged in sheets, aberrant keratinization with variable number of ghost cells. Dentinoid or osteodentin-like material is formed directly adjacent to the epithelial cells.

Benign mesenchymal odontogenic tumors

Odontogenic fibroma

Odontogenic myxoma/myxofibroma Cementoblastoma Cemento-ossifying fibroma
It can be intraosseous or extraosseous. It consists of mature fibrous connective tissue with variable amount of inactive-looking odontogenic epithelium arranged in strands or islands. Calcification may be present.

Stellate and spindle cells dispersed with in abundant extracellular myxoid or myxofibrotic matrix.

Calcified cementum-like tissue, which is deposited directly on a tooth root.

It is an occifying fibroma that occurs in the tooth-bearing areas of the jaws. sex preference and it is most commonly found in the fourth to fifth decade of life (5).

These tumors arise from remnants of the odontogenic epithelium, such as cell rests of the dental lamina, a developing enamel organ, the lining of an odontogenic cyst or the basal cells of the oral mucosa (9). They mostly occur in the mandible (10). Conventional mandible ameloblastomas clinically present as a painless swelling of the posterior 

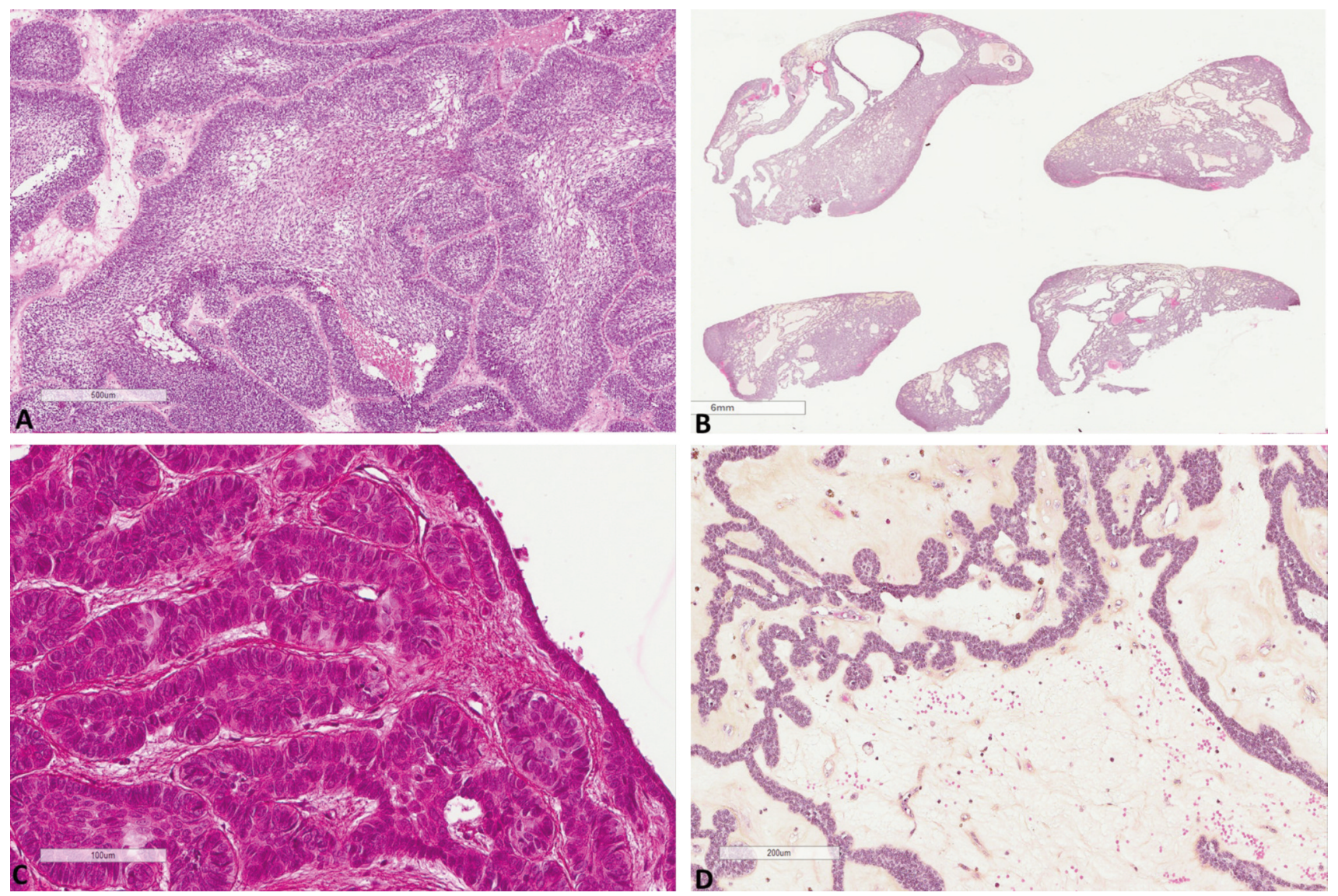

Figure 1. Different aspects of maxillary ameloblastomas. (A) Follicular pattern, showing large cell nests with palisading cell layers and a central part of stellate reticulum. (B) Microcystic areas can be seen. (C) Plexiform pattern, showing short strands of cells. (D) Plexiform pattern, showing very thin inter-anastomosing strands in an edematous background.

mandible, frequently being associated with an unerupted tooth and thus they can be easily detected (11).

The typical morphology of ameloblastomas is that of odontogenic epithelial islands simulating the stellate reticulum, peripherally palisaded by columnar cells with reversed nuclear polarity, filled with loosely arranged angulated cells (Figures 1 and 2, best appreciated in Figure 3D). No dentin or enamel (hard elements) formation is found. Ameloblastomas can present with a follicular, plexiform, acanthomatous, basaloid, granular cell or desmoplastic pattern, with no evidence of deviant biological behavior among them (Figure 1) (5). It is not uncommon to have a combination of two or more patterns in a tumor. The follicular pattern is the most common answered (5). It consists of neoplastic cellular nests with central loosening of short spindled epithelial cells resembling the stellate reticulum of the developing tooth germ, surrounded by palisading columnar cells with reverse nuclear polarity. The plexiform pattern shows a lace like architecture consisting of lamina like strands which show two distinct forms: one where the strands are formed by two layers of basaloid cells and a second form where the strands are thicker and looser and the cells have a more squamous appearance. In both cases, this pattern can be deceiving as there is no evident peripheral palisading and reverse nuclear polarity. The acanthomatous pattern shows squamous metaplasia within the stellate reticulum with formation of keratin filled cavities. Granular cell type is characterized by granular change where all or some of the neoplastic cells of the stellate reticulum gain abundant deeply granular cytoplasm (accumulation of lysosomes). The basaloid ameloblastoma shows nuclear crowding and cells with basaloid appearance with or without peripheral palisading or reverse nuclear polarity. The desmoplastic variant is characterized by intense stromal desmoplasia which compresses the neoplastic islands of the epithelium, making it difficult if not impossible to identify the peripheral palisading and reverse nuclear polarity. Extra osseous/peripheral type ameloblastomas can show the same histological patterns as described above, but the follicular, plexiform and acanthomatous patterns, are the ones most commonly seen (5). 

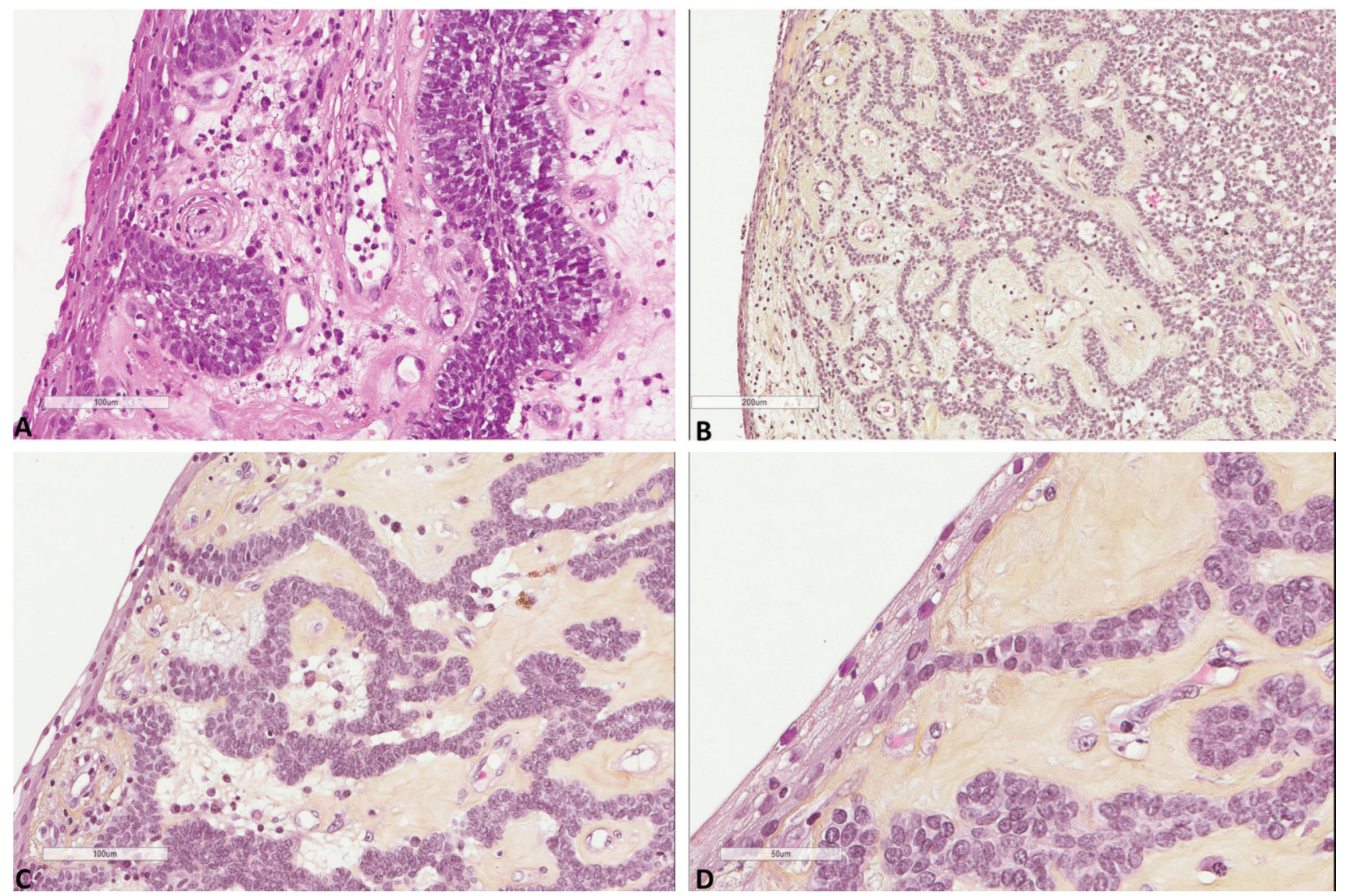

Figure 2. Continuity of tumor cells with surface epithelium. Three different cases of maxillary ameloblastomas (C and D, same case in different magnifications) showing the surface epithelium (left) communicating with the underlying tumor nests.

Recent studies have detected gene mutations in the mitogen-activated protein kinase (MAPK) pathway in most ameloblastomas, with mutations most commonly being $B R A F$ V600E as well as KRAS, NRAS, HRAS, and FGFR2 mutations (12).

Simple curettage of the neoplasm is linked to high incidence of recurrence (13). The current treatment of choice is wide surgical excision, including normal bone extending beyond the radiographical margins (5).

\section{Maxillary ameloblastoma}

Epidemiology. Ameloblastomas located in the maxillary region are rare compared to those arising in the mandible, the latter being five times more frequent (10). Indeed, maxillary ameloblastomas account for $15 \%$ of all ameloblastomas. Most of them arise posterior to the premolars and only $2 \%$ of them arise anterior to them (6, $10,13)$. The natural history, epidemiology, localization, histopathology and prognostic factors remain unclear since there are only a few case series referring exclusively to maxillary ameloblastomas (Table II). A wide range of ages has been reported for maxillary ameloblastoma, starting from early childhood, with a case of a six-yearold child being the younger patient reported (14) until elderly people with a case of an 81-year-old male were reported (15). It is worth noting that maxillary ameloblastomas occur about 10 years later than those arising in the mandible (11), probably representing the lack of evident early symptoms, while no sex predilection is found (16).

Signs and symptoms. Interestingly, maxillary ameloblastomas in contrast to mandibular ones, have a more aggressive clinical course (10). This is partially explained by the lack of early symptoms, leading to diagnosis at an advanced disease when the tumor has already extended beyond the maxilla (16, 17). When symptoms do develop, they include face deformity, usually unilateral, intraoral ulceration, toothache, headache, nasal obstruction, nasal epistaxis and visual disturbances $(18,19)$. Another reason for their aggressive behavior is the nature of the maxillary bone (20). In contrast to the compact mandible bone, the maxilla is a cancellous 

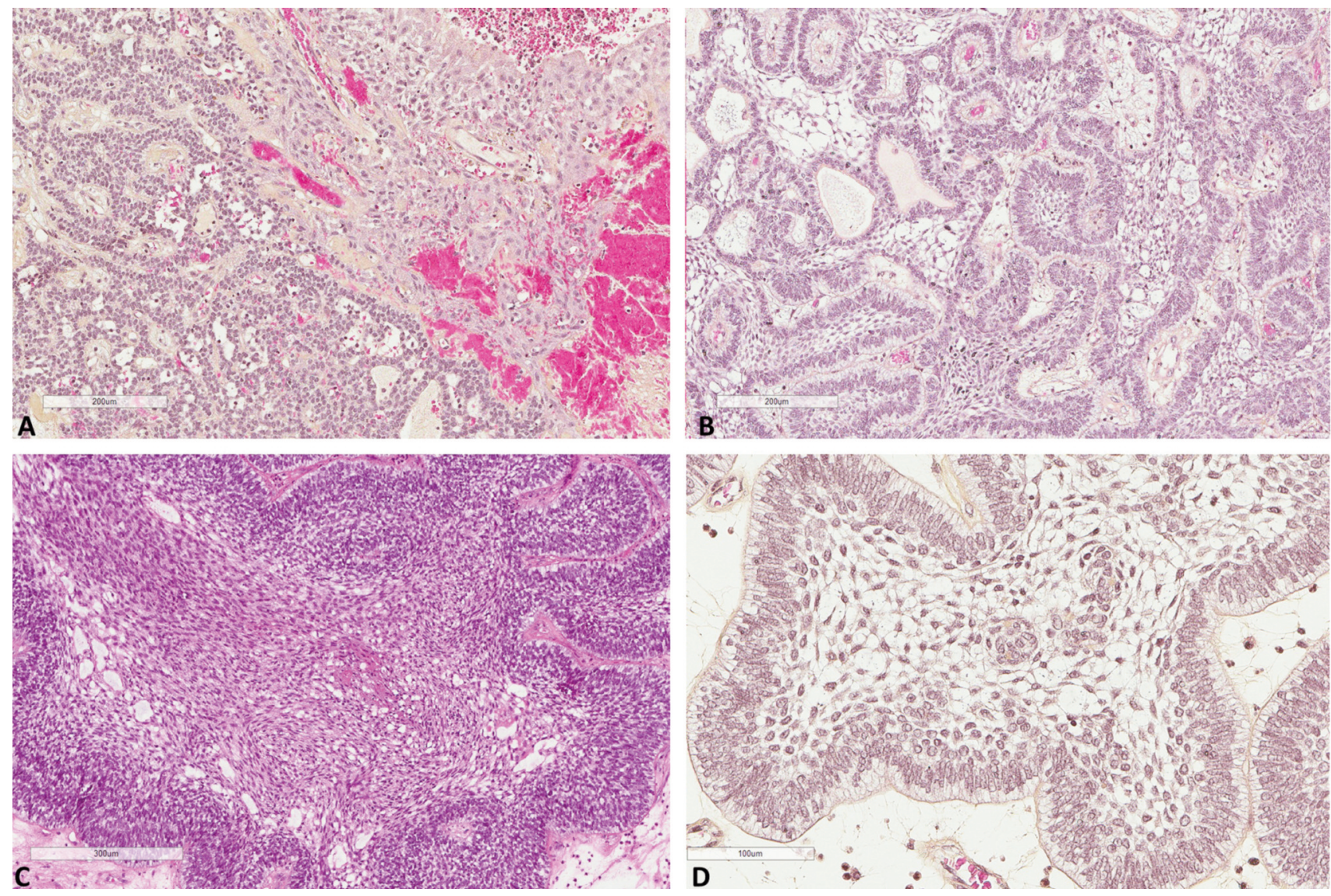

Figure 3. (A) Different components can be seen in the same tumor (left plexifom, right acanthomatous). (B) Follicular type maxillary ameloblatoma with evident stellate reticulum and palisading. (C) Follicular maxillary ameloblastoma with central spindle squamous cells. (D) The characteristic palisading cells with reversed polarity surrounding central stellate reticulum.

bone, making it easier for the tumor to invade and spread to adjacent structures such as the nasal cavity, paranasal sinuses, orbits, parapharyngeal tissues and skull base (2).

Histogenesis. The histogenesis of maxillary ameloblastomas remains controversial. In our experience, almost all maxillary ameloblastomas will show continuity of the tumoral cells with the overlying epithelium, if thoroughly examined (Figure 3). It has been suggested that maxillary ameloblastoma can derive from the odontogenic epithelium as mentioned above, but given this direct continuity with the overlying mucosal epithelium, an origin from the basal cells has been also hypothesized (15). Ide et al. studied 14 small ameloblastomas of the alveolar region and suggested that residues of odontogenic epithelium can be detected in all facial tissues, whether that is bone, the alveolar process or the gingiva (21). Thus, based on the latter theory, maxillary ameloblastomas can potentially arise everywhere within the maxillary region, without necessarily having direct contact with the teeth.
Location. The maxilla is a bone forming various facial cavities and walls. It is the roof of the mouth, the floor and lateral wall of the nasal cavity and the orbital floor. Thus, it forms part of the oral and nasal cavity, the maxillary sinus and part of the orbital cavity. Ameloblastomas can develop in all maxillary walls and cavities, in which case they are considered maxillary ameloblastomas. Physicians should carefully examine if these tumors are in contact with the maxillary bone. If the ameloblastoma is limited to the soft tissues, then it is considered to be of peripheral/extraosseous type. If bone infiltration is found, then additional characteristics should be used in order to classify it into the categories of conventional or unicystic, as described above for mandible ameloblastomas (Figure 4).

For descriptive reasons, maxillary ameloblastomas are also divided in posterior or anterior tumors (11). The first one is located posterior to the canine, thus it includes the molars and tuberosity and the second one is located anterior to the canine. Some authors also include the middle maxilla as a region of ameloblastomas origin, when they are situated between the 
Table II. Maxillary ameloblastoma. Characteristics of published cases.

\begin{tabular}{|c|c|c|c|c|c|c|c|c|}
\hline & $\begin{array}{r}\text { No of } \\
\text { Maxi } \\
\text { all c }\end{array}$ & $\begin{array}{l}\text { cases } \\
\text { lary/ } \\
\text { ases }\end{array}$ & Age & Gender & Location & $\begin{array}{l}\text { Histologic } \\
\text { type }\end{array}$ & Recurrence & Metastasis \\
\hline \multirow[t]{2}{*}{$\begin{array}{l}\text { Rockoff } \\
\text { et al. } \\
1963 \text { (32) }\end{array}$} & $\begin{array}{l}\text { SMALL IA } \\
1951\end{array}$ & $173 / 925$ & $\begin{array}{c}32.7 \\
\text { average } \\
\text { All cases }\end{array}$ & $473 \mathrm{~F}: 514 \mathrm{M}$ & $\begin{array}{c}47 \% \text { molar area } \\
33 \% \text { antrum and } \\
\text { floor of nose } \\
9 \% \text { premolar area } \\
9 \% \text { canine area } \\
2 \% \text { palate }\end{array}$ & NA & NA & NA \\
\hline & $\begin{array}{l}\text { ROBINSON } \\
\text { H.B.G. } 1937\end{array}$ & $48 / 295$ & $\begin{array}{c}30.1 \\
\text { average } \\
\text { All cases }\end{array}$ & $\begin{array}{l}\text { 142F: } 149 \mathrm{M} \\
\text { All cases }\end{array}$ & NA & NA & NA & NA \\
\hline $\begin{array}{l}\text { Sehdev } \\
\text { et al. } \\
1974 \text { (13) }\end{array}$ & $20 / 92$ & & NA & $9 \mathrm{~F}: 11 \mathrm{M}$ & NA & $\begin{array}{l}\text { Follicular and } \\
\text { plexiform most } \\
\text { commonly }\end{array}$ & $\begin{array}{c}2 / 2 \text { after } \mathrm{RT} \\
11 / 11 \text { after } \\
\text { initial curettage } \\
1 / 3 \text { treated with } \mathrm{RM} \\
1 / 2 \text { after } \mathrm{PM}\end{array}$ & $\begin{array}{l}1 \text { with pleuro- } \\
\text { pulmonary } \\
\text { metastases }\end{array}$ \\
\hline $\begin{array}{l}\text { Shaw and } \\
\text { Katsikas } \\
1973(18)\end{array}$ & $4 / 15$ & & $10-81$ & $1 \mathrm{~F}: 3 \mathrm{M}$ & NA & Adamantinoma & $2 / 4$ & NA \\
\hline $\begin{array}{l}\text { Tsaknis et al. } \\
1980 \text { (3) }\end{array}$ & NA & & $\begin{array}{c}45.6 \\
\text { average }\end{array}$ & $1 \mathrm{~F}: 2.4 \mathrm{M}$ & $\begin{array}{c}88 \% \text { canine } \\
\text { (posterior) }\end{array}$ & Follicular mixed & NA & NA \\
\hline $\begin{array}{l}\text { Bredenkam P } \\
\text { et al. } \\
1989 \text { (33) }\end{array}$ & 6 & & $15-69$ & $2 \mathrm{~F}: 6 \mathrm{M}$ & NA & $\begin{array}{c}\text { Conventional: } \\
1 \text { Mixed, } 2 \text { follicular, } \\
2 \text { plexiform, } 1 \text { NA }\end{array}$ & 4 cases & NA \\
\hline $\begin{array}{l}\text { Nastri et al. } \\
1995 \text { (22) }\end{array}$ & 13 & & $24-70$ & $9 \mathrm{~F}: 4 \mathrm{M}$ & $\begin{array}{l}9 \text { posterior } \\
\text { maxilla } \\
3 \text { middle } \\
\text { maxilla } \\
1 \text { anterior } \\
\text { maxilla }\end{array}$ & $\begin{array}{l}\text { Conventional: } \\
4 \text { follicular } \\
7 \text { mixed } \\
\text { (4 follicular \& } \\
\text { acanthomatous, } \\
3 \text { follicular and } \\
\text { plexiform) } \\
\text { Unicystic: } \\
1 \text { plexiform }\end{array}$ & 3 patients & NA \\
\hline $\begin{array}{l}\text { Reichart } \\
\text { et al. } \\
1995 \text { (11) }\end{array}$ & $*$ & & $\begin{array}{c}\text { Average } \\
35.9 \%\end{array}$ & $1 \mathrm{~F}: 1.14 \mathrm{M}$ & $\begin{array}{c}49 \% \text { molar region } \\
14 \% \text { maxillary } \\
\text { sinus } \\
5 \% \text { nasal } \\
\text { cavity }\end{array}$ & $\begin{array}{c}\text { Follicular, } \\
\text { plexiform, } \\
\text { acanthomatous } \\
\text { and mixed are the } \\
\text { most common } \\
\text { variants }\end{array}$ & $\begin{array}{l}\text { Recurrence is } \\
\text { twice as often } \\
\text { in conservative } \\
\text { therapy than } \\
\text { in radical }\end{array}$ & NA \\
\hline $\begin{array}{l}\text { Schafer } \\
\text { et al. } \\
1998 \text { (15) }\end{array}$ & 24 & & $43-81$ & $5 \mathrm{~F}: 19 \mathrm{M}$ & $\begin{array}{c}\text { Maxillary } \\
\text { sinus or } \\
\text { nasal cavity }\end{array}$ & $\begin{array}{l}\text { Conventional: } \\
22 \text { plexiform } \\
2 \text { follicular }\end{array}$ & 6 cases & NA \\
\hline $\begin{array}{l}\text { Zwahlen } \\
\text { et al. } \\
2002 \text { (16) }\end{array}$ & $5 / 26$ & & $26-73$ & $3 \mathrm{~F}: 2 \mathrm{M}$ & $\begin{array}{l}\text { Maxillary sinus, } \\
\text { maxillary alveolar } \\
\text { ridge, maxillary } \\
\text { tuberosity, palate, } \\
\text { sphenoidal sinus, } \\
\text { ethmoidal } \\
\text { complex }\end{array}$ & $\begin{array}{l}\text { Conventional: } \\
3 \text { follicular } \\
1 \text { desmoplastic } \\
1 \text { acanthomatous } \\
2 \text { mixed: } \\
\text { follicular \& } \\
\text { plexiform }\end{array}$ & $\begin{array}{c}2: 5 \\
1 \text { after } \\
\text { curettage } \\
1 \text { aftere n-block } \\
\text { resection }\end{array}$ & $\begin{array}{l}1: 5 \\
\text { brain, lungs, } \\
\text { myocardium }\end{array}$ \\
\hline $\begin{array}{l}\text { Darshani } \\
\text { Gunawardhana } \\
\text { et al. } \\
2010 \text { (34) }\end{array}$ & $31 / 286$ & & NA & $15 \mathrm{~F}: 16 \mathrm{M}$ & $\begin{array}{c}7 \text { anterior } \\
7 \text { premolar } \\
7 \text { posterior } \\
5 \text { premolar+anterior } \\
2 \text { premolar+anterior } \\
+ \text { posterior } \\
3 \text { not specified }\end{array}$ & $\begin{array}{l}\text { Conventional: } \\
2 \text { follicular, } \\
2 \text { plexiform, } \\
2 \text { acanthomatous, } \\
1 \text { mixed, } \\
9 \text { desmoplastic } \\
\text { Unicystic: } 15\end{array}$ & $\begin{array}{c}\text { Both mandible } \\
\text { and maxillary } \\
20 / 56 \text { after } \\
\text { curettage } \\
2 / 27 \text { after } \\
\text { radical } \\
\text { resection }\end{array}$ & NA \\
\hline
\end{tabular}


Table II. Continued

\begin{tabular}{|c|c|c|c|c|c|c|c|c|}
\hline & & & Age & Gender & Location & $\begin{array}{l}\text { Histologic } \\
\text { type }\end{array}$ & Recurrence & Metastasis \\
\hline $\begin{array}{l}\text { Cosola et al. } \\
2007 \text { (35) }\end{array}$ & & 10 & $\begin{array}{c}39.6 \\
\text { average }\end{array}$ & $1 \mathrm{~F}: 1.3 \mathrm{M}$ & $\begin{array}{c}7 \text { posterior } \\
3 \text { anterior } \\
2 \text { plexiform } \\
1 \text { acanthomatous } \\
1 \text { mixed } \\
\text { Unicystic: } 2\end{array}$ & $\begin{array}{l}\text { Conventional: } \\
4 \text { follicular }\end{array}$ & NA & NA \\
\hline $\begin{array}{l}\text { Ogunsalu } \\
\text { et al. } \\
2009(36)\end{array}$ & 6 & & $13-58$ & $1 \mathrm{~F}: 1 \mathrm{M}$ & $\begin{array}{c}5 \text { posterior } \\
1 \text { anterior }\end{array}$ & $\begin{array}{l}\text { Conventional: } \\
1 \text { follicular } \\
\text { Unicystic: } \\
1 \text { follicular } \\
\text { NA for the } \\
\text { rest cases }\end{array}$ & $\begin{array}{c}1 \text { after multiple } \\
\text { biopsies and } \\
\text { hemi-maxilectomy }\end{array}$ & NA \\
\hline $\begin{array}{l}\text { Yang et } \\
\text { al. } 2016 \text { (14) }\end{array}$ & $51 / 890$ & & $6-79$ & $13 \mathrm{~F}: 38 \mathrm{M}$ & $\begin{array}{l}15 \text { anterior } \\
36 \text { posterior }\end{array}$ & $\begin{array}{l}\text { Conventional: } \\
23 \text { folicular } \\
24 \text { plexiform } \\
4 \text { desmoplastic }\end{array}$ & $\begin{array}{l}29 \% \text { after resection } \\
10 \% \text { after curettage } \\
\text { ( } 46,7 \% \text { of the anterior } \\
\text { located and } 11,1 \% \text { of } \\
\text { the posterior located) }\end{array}$ & NA \\
\hline
\end{tabular}

RT: Radiotherapy, RM: radical maxilectomy, PM: partial maxilectomy. *This review includes case reports and reviews. Due to overlapping or missing data, the total number for each category varies, thus not included in this table. NA: Not available.

canine and maxillary molars (22). Ameloblastomas have a preference to the posterior maxilla, since only $2 \%$ have been reported to arise in the anterior region (22).

Histopathology. The most frequent histological patterns seen in maxillary ameloblastomas are the follicular and plexiform patterns followed by the acanthomatous one, which is observed as a part of mixed type frequently being focal and inconspicuous (Figures 1-3) (15, 22). Interestingly, the desmoplastic variant although being a rare variant, shows a predilection for the maxilla (23).

Immunohistochemistry. Although not pathognomonic, immunohistochemistry may be helpful in diagnosing ameloblastoma or excluding entities with histological characteristics similar to ameloblastoma (24). All ameloblastoma cells express CK19, which is considered an odontogenic epithelium marker, including areas of acanthomatous and granular differentiation $(25,26)$. The stellate reticulum cells usually stain for CK13 and Calretinin $(24,27)$, while the peripheral cells usually stain for CK14 and CD56 $(28,29)$. Ameloblastomas have a very low proliferation index (MıB1/Ki67), but malignant ameloblastomas can have a higher proliferation rate of almost 20\% (30).

Differential diagnosis. A pathologist should be careful when rendering a diagnosis of ameloblastoma. Not only should he include the possibility of such diagnosis in lesions of the maxillary lesion, but he should also exclude several entities that share similar histological features before reaching his final diagnosis.

Sinonasal papilloma enters this differential diagnosis especially due to to the sinonasal location; inverted papilloma may show some overlapping histological features with ameloblastoma, especially the follicular and acanthomatous ones. However, epithelial cells of inverted papillomas show absence of reversed nuclear polarity, actual absence of stellate reticulum, and there is a basement membrane surrounding nests as well as numerous intraepithelial microcysts mostly containing neutrophils, both findings characteristic of the inverted sinonasal papilloma.

Ameloblastic and odontogenic fibromas characteristically have smaller nests, that generally do not fuse or anastomose and are set in an a more myxoid matrix with numerous stellate fibroblasts. Ameloblastic odontomas have similar epithelial elements as ameloblastoma but they also include hard elements (enamel and dentin). In contrast to ameloblastoma, adenomatoid odontogenic tumor has reverse polarity away from a central lumen and not in the basal layer surrounding nests of cells resembling the stellate reticulum (Table III).

Non-keratinizing squamous cell carcinoma has an anastomosing ribbon like architectural pattern that could resemble ameloblastoma, especially the plexiform pattern, 


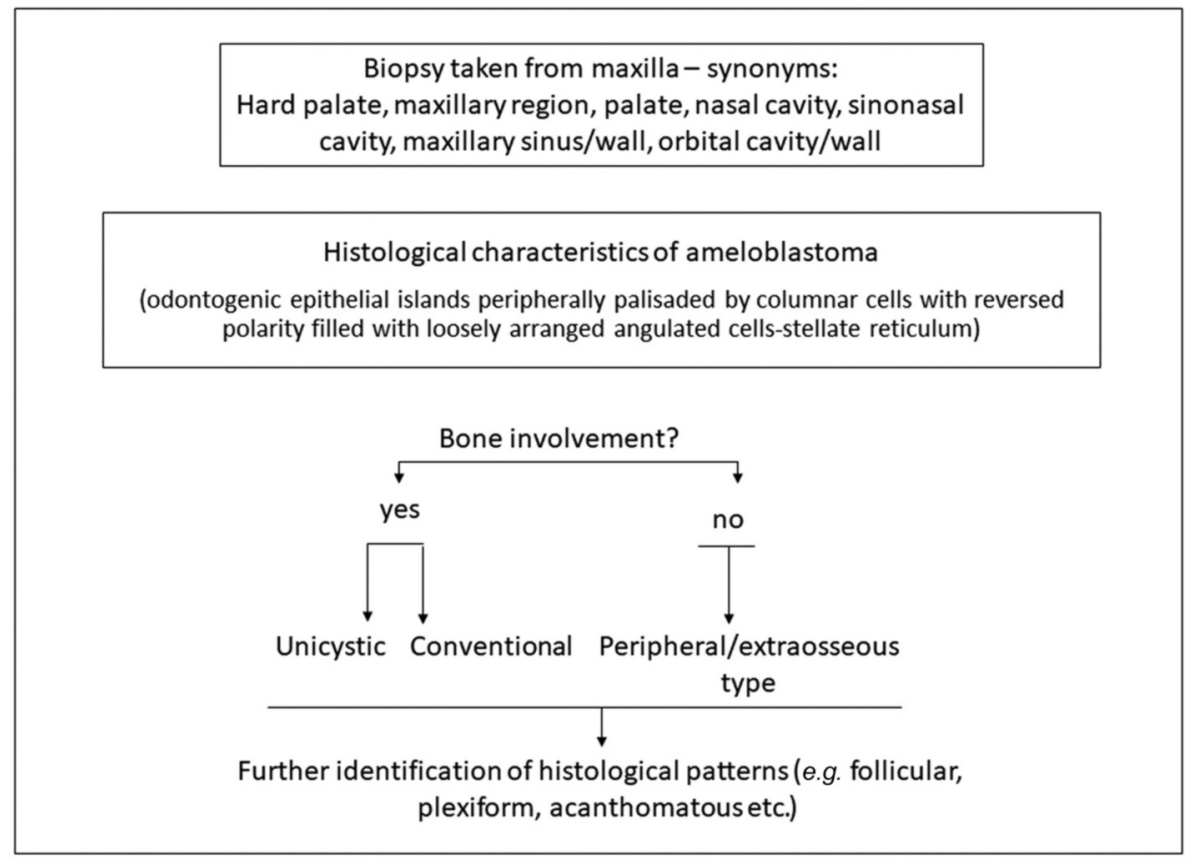

Figure 4. Maxillary ameloblastomas diagnostic approach.

Table III. Suggested references for further reading.

Yang et al. (14)

Darshani Gunawardhana et al. (34)

Reichart et al. (11)

Sweeney et al. (12)

Slootweg (37)

Bilodeau et al. (38)

Wright et al. (39)
One of the largest and most recent series of ameloblastoma with prognostic data

Another large series comparing maxillary with mandibular ameloblastomas

Molecular profile of ameloblastomas

Molecular profile of ameloblastomas

Description of tooth formation to better understand odontogenic lesions

A useful introduction in odontogenic tumors

A useful introduction in odontogenic and maxillofacial bone tumors but there is marked nuclear atypia, loss of polarity and numerous mitoses, characteristics not compatible to the latter. Adenoid cystic carcinoma (ACC) in its typical form with cribriform structures may not be a diagnostic problem, however, its solid variant should enter the differential diagnosis of ameloblastoma. Immunohistochemical expression of CD117 in ACC cells could be helpful in this case. Mucoepidermoid carcinoma, may resemble ameloblastoma but attentive examination reveals three cell types, mucous, squamous and intermediate. Basal cell adenocarcinoma is a rare, yet worth to be included in the differential diagnosis entity. The main histological findings are the lack of reverse nuclear polarity, as well as the architectural pattern of basal cell adenocarcinoma, which shows a more confluent pattern rather than the anastomosing pattern seen in ameloblastomas. Basal cell carcinoma can be easily excluded immunohistochemically using keratin 19 which is negative in basal cell carcinoma and positive in ameloblastoma (31).

Molecular biology. Maxillary ameloblastomas, as the mandibular ones, have been associated with certain gene mutations. Interestingly, maxillary amenoblastomas do not have the same gene mutations as the mandibular ones. They most frequently harbor a SMO mutation followed by a $R A S$ mutation and less frequently a $B R A F$ or FGFR2 mutation (12).

Treatment. Despite the fact that treatment for mandibular ameloblastomas is relatively well defined, treatment for maxillary ameloblastomas has not yet been established. In brief, simple curettage of maxillary ameloblastomas has up to $100 \%$ possibility of local recurrence (13). In contrast, 
more radical approaches, such as en bloc resection with the possibility of 10-15 mm thickness of normal bone as margin, have shown lower percentages of recurrence (13).

\section{Conclusion}

Ameloblastomas are odontogenic epithelial tumors mostly involving the mandible. Maxillary ameloblastomas, on the other hand, are rare and therefore not easy to be suspected. After collecting available literature data, we showed that there is no sex predilection and that maxillary ameloblastoma can arise in all ages, but a decade later than the mandible ones. They can be found anywhere within the maxillary region and they are not necessarily associated to a tooth. The follicular and plexiform types are the most frequently observed histological patterns. In contrast to mandible ameloblastomas, the maxillary ones show SMO mutations followed by $R A S$ mutations and only a few have $B R A F$ and FGFR2 mutations. Excision should be wider for patients with maxillary ameloblastomas since it shows a more aggressive behavior threatening neighboring structures.

\section{Conflicts of Interest}

The Authors have no conflicts of interest to disclose.

\section{Authors' Contributions}

All Authors contributed to data collection and analysis. ZE drafted the manuscript. All Authors revised and approved the final form.

\section{References}

1 Broca P: Recherches sur un nouveau groupe de tumeurs désignées sous le nom d'odontomes (ed.1867). HACHETTE BNF, 2017.

2 Gardner DG: A pathologist's approach to the treatment of ameloblastoma. J Oral Maxillofac Surg 42: 161-166, 1984. PMID: 6583361. DOI: 10.1016/s0278-2391(84)80026-9

3 Thoma KH and Goldman HM: Odontogenic tumors: classification based on observations of the epithelial, mesenchymal, and mixed varieties. Am J Pathol 22: 433-471, 1946. PMID: 19970874.

4 Pindborg JJ: A calcifying epithelial odontogenic tumor. Cancer 11: 838-843, 1958. PMID: 13561253. DOI: 10.1002/10970142(195807/08)11:4<838::AID-CNCR2820110423>3.0.CO;2-5

5 El-Naggar AK, Chan JKC, Grandis JR, Takata T and Slootweg PJ: WHO classification of head and neck tumours. WHO/IARC classification of tumours. World Heal Organ, 2017.

6 Small IA and Waldron CA: Ameloblastomas of the jaws. Oral Surgery, Oral Med Oral Pathol 8: 281-297, 1955. PMID: 14356722. DOI: $10.1016 / 0030-4220(55) 90350-9$

7 Larsson A and Almeren H: Ameloblastoma of the jaws. An analysis of a consecutive series of all cases reported to the Swedish cancer registry during 1958-1971. Acta Pathol Microbiol Scand - Sect A Pathol 86: 337-349, 1978. PMID: 716895. DOI: 10.1111/j.1699-0463.1978.tb02054.x
8 Shear M and Singh S: Age-standardized incidence rates of ameloblastoma and dentigerous cyst on the Witwatersrand, South Africa. Community Dent Oral Epidemiol 6: 195-199, 1978. PMID: 278703. DOI: 10.1111/j.1600-0528.1978.tb01149.x

9 Gorlin RJ, Chaudhry AP and Pindborg JJ: Odontogenic tumors. Classification, histopathology, and clinical behavior in man and domesticated animals. Cancer 14: 73-101, 1961. PMID: 13707265. DOI: 10.1002/1097-0142(196101/02)14:1<73::AIDCNCR2820140111>3.0.CO;2-T

10 Robinson HBG: Ameloblastoma: a survey of 379 cases from the literature. Arch Pathol 23: 440, 1937.

11 Reichart PA, Philipsen HP and Sonner S: Ameloblastoma: Biological profile of 3677 cases. Eur J Cancer Part B Oral Oncol 31: 86-99, 1995. PMID: 7633291. DOI: 10.1016/09641955(94)00037-5

12 Sweeney RT, McClary AC, Myers BR, Biscocho J, Neahring L, Kwei KA, Qu K, Gong X, Ng T, Jones CD, Varma S, Odegaard JI, Sugiyama T, Koyota S, Rubin BP, Troxell ML, Pelham RJ, Zehnder JL, Beachy PA, Pollack JR and West RB: Identification of recurrent SMO and BRAF mutations in ameloblastomas. Nat Genet 46: 722-725, 2014. PMID: 24859340. DOI: 10.1038/ ng. 2986

13 Sehdev MK, Huvos AG, Strong EW, Gerold FP and Willis GW: Ameloblastoma of maxilla and mandible. Cancer 33: 324-333, 1974. PMID: 5318030. DOI: 10.1002/1097-0142(197402)33: 2<324::AID-CNCR2820330205>3.0.CO;2-U

14 Yang R, Liu Z, Peng C, Cao W and Ji T: Maxillary ameloblastoma: Factors associated with risk of recurrence. Head Neck 39: 996-1000, 2017. PMID: 20848441. DOI: 10.1002/ hed. 24720

15 Schafer DR, Thompson LDR, Smith BC and Wenig BM: Primary ameloblastoma of the sinonasal tract: A clinicopathologic study of 24 cases. Cancer 82: 667-674, 1998. PMID: 9477098. DOI: 10.1002/(SICI)1097-0142(19980215)82: 4<667::AID-CNCR8>3.0.CO;2-I

16 Zwahlen RA and Grätz KW: Maxillary ameloblastomas: A review of the literature and of a 15-year database. J CranioMaxillofacial Surg 30: 273-279, 2002. PMID: 12377199 . DOI: 10.1016/S1010-5182(02)90317-3

17 Corio RL, Goldblatt LI, Edwards PA and Hartman KS: Ameloblastic carcinoma: A clinicopathologic study and assessment of eight cases. Oral Surgery, Oral Med Oral Pathol 64: 570-576, 1987. PMID: 3313152. DOI: 10.1016/0030-4220(87)90063-6

18 Shaw HJ and Katsikas DK: Ameloblastoma of the maxilla a clinical study with four cases. J Laryngol Otol 87: 873-884, 1973. PMID: 4728301. DOI: 10.1017/S0022215100077744

19 Abtahi MA, Zandi A, Razmjoo H, Ghaffari S, Abtahi SM, Jahanbani-Ardakani H, Kasaei Z, Kasaei-Koupaei S, Sajjadi S, Sonbolestan SA and Abtahi SH: Orbital invasion of ameloblastoma: A systematic review apropos of a rare entity. J Curr Ophthalmol 30: 23-34, 2018. PMID: 9788857. DOI: 10.1016/j.joco.2017.09.001

20 Batsakis JG and Mcclatchey KD: Ameloblastoma of the maxilla and peripheral ameloblastomas. Ann Otol Rhinol Laryngol 92: 532533, 1983. PMID: 6625456. DOI: 10.1177/000348948309200526

21 Ide F, Mishima K, Yamada H, Horie N, Saito I, Shimoyama T and Kusama K: Unsuspected small ameloblastoma in the alveolar bone: A collaborative study of 14 cases with discussion of their cellular sources. J Oral Pathol Med 37: 221-227, 2008. PMID: 18221325. DOI: 10.1111/j.1600-0714.2007.00628.x 
22 Nastri AL, Wiesenfeld D, Radden BG, Eveson J and Scully C: Maxillary ameloblastoma: a retrospective study of 13 cases. $\mathrm{Br}$ J Oral Maxillofac Surg 33: 28-32, 1995. PMID: 7718524. DOI: 10.1016/0266-4356(95)90082-9

23 Philipsen HP, Reichart PA and Takata T: Desmoplastic ameloblastoma (including "hybrid" lesion of ameloblastoma). Biological profile based on 100 cases from the literature and own files. Oral Oncol 37: 455-460, 2001. PMID: 11377234. DOI: $10.1016 / \mathrm{S} 1368-8375(00) 00111-1$

24 Hunter KD and Speight PM: The diagnostic usefulness of immunohistochemistry for odontogenic lesions. Head Neck Pathol 8: 392-399, 2014. PMID: 25409846. DOI: 10.1007/ s12105-014-0582-0

25 Pal SK, Sakamoto K, Aragaki T, Akashi T and Yamaguchi A: The expression profiles of acidic epithelial keratins in ameloblastoma. Oral Surg Oral Med Oral Pathol Oral Radiol 115: 523-531, 2013. PMID: 23522646. DOI: 10.1016/j.oooo.2013.01.017

26 Kishino M, Murakami S, Yuki M, Iida S, Ogawa Y, Kogo M and Toyosawa S: A immunohistochemical study of the peripheral ameloblastoma. Oral Dis 13: 575-580, 2007. PMID: 17944675. DOI: $10.1111 / \mathrm{j} .1601-0825.2006 .01340 . x$

27 Altini M, Coleman H, Doglioni C, Favia G and Maiorano E: Calretinin expression in ameloblastomas. Histopathology 37: 2732, 2000. PMID: 10931215. DOI: 10.1046/j.1365-2559.2000. 00940.x

28 Cairns L, Naidu A, Robinson CM, Sloan P, Wright JM and Hunter KD: CD56 (NCAM) expression in ameloblastomas and other odontogenic lesions. Histopathology 57: 544-548, 2010. PMID: 20875069. DOI: 10.1111/j.1365-2559.2010.03658.x

29 Kusafuka K, Hirobe K, Wato M, Tanaka A and Nakajima T: CD56 expression is associated with neuroectodermal differentiation in ameloblastomas: An immunohistochemical evaluation in comparison with odontogenic cystic lesions. Med Mol Morphol 44: 79-85, 2011. PMID: 21717310. DOI: 10.1007/ s00795-010-0510-7

30 Bologna-Molina R, Mosqueda-Taylor A, Lopez-Corella E, De Almeida OP, Carrasco-Daza D, Farfán-Morales JE, MolinaFrechero $\mathrm{N}$ and Damián-Matsumura P: Comparative expression of syndecan-1 and Ki-67 in peripheral and desmoplastic ameloblastomas and ameloblastic carcinoma. Pathol Int 59: 229233, 2009. PMID: 19351365. DOI: 10.1111/j.1440-1827.2009. 02355.x
31 Vanoven BJ, Parker NP and Petruzzelli GJ: Peripheral ameloblastoma of the maxilla: a case report and literature review. Am J Otolaryngol - Head Neck Med Surg 29: 357-360, 2008. PMID: 18722894. DOI: 10.1016/j.amjoto.2007.10.002

32 Rockoff HM: A statistical analysis of ameloblastoma. Oral Surgery, Oral Med Oral Pathol 16: 1100-1101, 1963. PMID: 14061145. DOI: 10.1016/0030-4220(63)90225-1

33 Bredenkamp JK, Zimmerman MC and Mickel RA: Maxillary Ameloblastoma: A Potentially Lethal Neoplasm. Arch Otolaryngol Neck Surg 115: 99-104, 1989. PMID: 2642382. DOI: 10.1001/archotol.1989.01860250101036

34 Darshani Gunawardhana KSN, Jayasooriya PR, Rambukewela IK and Tilakaratne WM: A clinico-pathological comparison between mandibular and maxillary ameloblastomas in Sri Lanka. J Oral Pathol Med 39: 236-241, 2010. PMID: 20070485. DOI: 10.1111/j.1600-0714.2009.00850.x

35 Di Cosola M, Turco M, Bizzoca G, Tavoulari K, Capodiferro S, Escudero Castaño N and Lo Muzio L: Ameloblastoma of the jaw and maxillary bone: clinical study and report of our experience. Av Odontoestomatol 23: 367-373, 2007.

36 Ogunsalu C, Scipio E and Williams N: Review of six cases of maxillary ameloblastoma from the West Indies re-entry cryosurgery as prophylactic surgical intervention. West Indian Med J 58: 398-403, 2009. PMID: 20099786.

37 Slootweg PJ: Update on tooth formation mimicking odontogenic neoplasia. Head Neck Pathol 1: 94-98, 2007. PMID: 20614289. DOI: $10.1007 / \mathrm{s} 12105-007-0011-8$

38 Bilodeau EA and Seethala RR: Update on odontogenic tumors: Proceedings of the North American Head and Neck Pathology Society. Head Neck Pathol 13: 457-465, 2019. PMID: 30887391. DOI: 10.1007/s12105-019-01013-5

39 Wright JM and Vered M: Update from the 4th Edition of the World Health Organization Classification of Head and Neck Tumours: Odontogenic and Maxillofacial Bone Tumors. Head Neck Pathol 11: 68-77, 2017. PMID: 28247226. DOI: 10.1007/ s12105-017-0794-1

Received June 18, 2020

Revised July 7, 2020

Accepted July 9, 2020 